\title{
EFFECT OF DIFFERENT PLANTING DATES AND ORGANIC FERTILIZERS TREATMENTS ON GROWTH AND YIELD OF HIBISCUS SABDARIFFA L. PLANTS
}

\author{
Elham M. Attia and Rania M. Khater* \\ Department of Medicinal and Aromatic Plants, Desert Research \\ Center, Matareya Cairo, Egypt \\ *E-mail: dr.raniakhater@yahoo.com
}

$\mathrm{T}$

his research was conducted at the El-Qantara Sharq Research Station, Desert Research Center, during two successive summer seasons of 2013 and 2014 to study the effect of planting dates $\left(15^{\text {th }}\right.$ April, $1^{\text {st }}$ May and $15^{\text {th }}$ May) and organic fertilization treatments (control, $15 \mathrm{~m}^{3} /$ feddan cattle manure, $15 \mathrm{~m}^{3} /$ feddan compost and a mixture of organic fertilizers [15 $\mathrm{m}^{3} /$ feddan compost $+15 \mathrm{~m}^{3} /$ feddan cattle manure]) on growth, yield and active ingredients of Hibiscus sabdariffa L. plants.

Early planting date $\left(15^{\text {th }}\right.$ April) resulted in significant increase in all growth characters, while delaying the planting dates decreased it in both seasons. The application of organic fertilizers produced the highest value in all growth characters during the two experimental seasons, while the treatment of mixed organic fertilizer significantly increased vegetative growth parameters, chemical ingredients and the chemical constituents. The interaction between planting dates and organic fertilization show that, the treatment of cultivation date on $15^{\text {th }}$ April and fertilization with mixed organic fertilizer significantly increased most of the studied characters, however this treatment gave the maximum sepals per plant and per feddan, yield of seeds per plant and per feddan, the anthocyanins content and fixed oil content in seeds compared with the other treatments.

Keywords: Hibiscus sabdariffa, planting dates, organic fertilization, compost, cattle manure

Roselle (Hibiscus sabdariffa L.), commonly known as "Karkade" in Egypt and most Arab countries, belongs to the family Malvaceae (Mohamed et al., 2007). Dried fleshly calices is the part of the flower used as having a large quantities of organic acids, vitamin $\mathrm{C}$, and the therapeutic properties of diuretic acids and anthocyanins (Peng-Kong et al., 2002). Roselle plant is one of the most important medicinal plants cultivated in the tropical and 
subtropical countries. The drink of "Karkade" made of calyx has many medicinal uses for killing various types of bacteria and microorganisms, remedy for cancer, has soporific action, and has a favorable effect on the functions of the stomach possession (Aziz et al., 2007). It decreases blood pressure and causes relaxation of the rest parts of the human body. The flowers of 'roselle' are suitable to be used as natural food coloring agents, and the red beverage is also used in jams, tea pies, deserts and sauces. Sanyo (1981) reported that the plant is a good source for lipid-soluble antioxidant and particularly g'tocopherol.

Organic fertilizers are safe for human health and environment, and are made by recycling of organic waste materials from animal, plants, or food scraps in a controlled process. Compost increases soil organic matter, provides and facilitates the absorption of nutrients. Mathur et al. (1993) and Tara et al. (1996) mentioned that adding different composts to the soil caused remarkable improvement of different growth characters, of medicinal and aromatic plants; such as peppermint (Tara et al., 1996), and Rosmarinus officinalis and Tagetes erecta (Khalil, 2002). Compost is used to improve water retention capacity, draining, $\mathrm{pH}$ and better availability of soil microorganism (Khandar and Nigam, 1986 and Herrera et al., 1997). In this concern, Badran and Safwat (2004), on fennel plants, the organic manure has promoted flowering and increased sepals' productions by enhancing the nitrogen content and the rate of photosynthesis.

Sowing date is an important factor in crop production, performance and yield. Sowing date affects the quality of calyxes consumer acceptability's based on calyx quality in terms of color, taste, calyx size, aroma, and yield. Roselle a tropical annual shrub, which fruit like structures containing eligible pigment belongs to family Malvaceae (Ghazali, 1999). Roselle calices were being shipped to Germany, France, Switzerland and Italy at the rate of 10 to 25 tons annually (Morton, 1987), but now it is considered one of the competitive beverages in the world (Schippers, 2000). Roselle is tolerant to a wide range of environmental conditions, well-suited to cultivation in hot and dry regions on a wide range of soils, requiring a short day of 12 to 13 hours (Tindal, 1983). The explanation for the relative earliness of sown roselle date is due to temperature and photosensitivity, such plant would flower early in condition of short sunlight durations and may not flower when sunlight duration is above 11 hours (Twain et al., 2001). Depending on the variety, it matures from 12 to 16 weeks from sowing date, where diseases and pest are rarely serious. Rain, high humidity, and drying during the harvest time can downgrade the quality of the calices and reduce the yield.

Some studies of planting dates in Hibiscus sabdariffa plant found that, the early planting dates gave the highest values of plant heights, number of branches, fresh and dry weight of plant, sepals, seeds also early planting dates increased $\mathrm{N}, \mathrm{P}, \mathrm{K}$ and total carbohydrates percentage, acidity and 
anthocyanin in sepals and fixed oil in seeds (Futuless et al., 2010; Okosun, 2000; Babatinde et al., 2002; Oyewole and Mera, 2010; Seghatoleslami et al., 2013; Nnebue et al., 2014; Timothy and Futuless, 2014 and Ado et al., 2015).

This study was conducted to evaluate the effect of sowing date and organic fertilizers on vegetative growth, yield production and active ingredients of Hibiscus sabdariffa plants in new reclamation areas.

\section{MATERIALS AND METHODS}

This investigation was carried out at the Experimental Station of Desert Research Center at El-Qantara Sharq, North Sinai, Egypt, for two successive seasons of 2013 and 2014. Seeds of roselle (Hibiscus sabdariffa) were sown in the field plots $(5 \times 5 \mathrm{~m})$, each plot contained 50 plants, since the distance between rows was $100 \mathrm{~cm}$ and between plants within row was 50 $\mathrm{cm}$. Seedlings were thinned to one plant per hill. The irrigation system of the experiment was drip irrigation with the rate of $4 \mathrm{l} / \mathrm{h} / \mathrm{hill}$. The mechanical and chemical properties of the experimental soil are shown in table (1).

Table (1). Physical and chemical analysis of soils of the experimental site at El-Qantara Sharq- North Sinai Research Station.

\begin{tabular}{|c|c|c|c|c|c|c|c|}
\hline \multirow[b]{2}{*}{$\begin{array}{l}\text { Mechanical } \\
\text { analysis }\end{array}$} & \multirow[b]{2}{*}{ Value } & \multicolumn{6}{|c|}{ Chemical analysis } \\
\hline & & $\begin{array}{c}\text { Soluble } \\
\text { anions } \\
(\mathrm{meq} / \mathrm{l})\end{array}$ & Value & $\begin{array}{l}\text { Soluble } \\
\text { cations } \\
(\mathrm{meq} / \mathrm{l})\end{array}$ & Valu & $\begin{array}{c}\text { Availabl } \\
(\mathrm{mg} / \mathrm{l})\end{array}$ & Value \\
\hline Fine sand \% & 43.28 & $\mathrm{CO}_{3}^{-}$ & - & $\mathrm{Ca}^{++}$ & 8.92 & $\mathbf{N}$ & 0.16 \\
\hline$\%$ & 42.26 & $\mathrm{Cl}^{-}$ & 9.00 & $\mathbf{M g}^{++}$ & 7.9 & $\mathbf{P}$ & 13.21 \\
\hline Sil & 13.28 & $\mathrm{SO}_{4}^{--}$ & 25.35 & $\mathbf{N a}^{+}$ & 20.42 & $\mathbf{K}$ & 69.67 \\
\hline Clay \% & 1.18 & pH & 8.29 & $\mathbf{K}^{+}$ & 1.21 & $\mathrm{CaCO}_{3}$ & 6.20 \\
\hline Soil texture & & Sandy & & $\begin{array}{c}\text { E.C mml } \\
\mathbf{c m}\end{array}$ & & 3.85 & \\
\hline
\end{tabular}

The experiment consisted of 12 treatments including combinations among planting date treatments $\left(15^{\text {th }}\right.$ April, $1^{\text {st }}$ May and $15^{\text {th }}$ May $)$ and different organic fertilization treatments (control, $15 \mathrm{~m}^{3} / \mathrm{fed}$ compost (comp.), $15 \mathrm{~m}^{3} / \mathrm{fed}$ cattle manure (C.M.) and a mixture of organic fertilizer $\left[15 \mathrm{~m}^{3} / \mathrm{fed}\right.$ compost $+15 \mathrm{~m}^{3} /$ fed cattle manure (M.O.F.)]). The chemical properties of experimental fertilization are shown in table (2). These treatments were arranged in a split plot design with three replicates. Planting date treatments were randomly arranged in the main plots, while the organic fertilizer levels treatments were randomly arranged in the sub plots. 
Table (2). Chemical analysis of compost and cattle manure at El-Qantara Sharq, North Sinai Research Station.

\begin{tabular}{|c|c|c|c|c|c|}
\hline Parameters & Compost & $\begin{array}{c}\text { Cattle } \\
\text { manure }\end{array}$ & Parameters & Compost & $\begin{array}{c}\text { Cattle } \\
\text { manure }\end{array}$ \\
\hline $\begin{array}{l}\text { Organic } \\
\text { matter }(\%)\end{array}$ & 63.35 & 39.13 & $\begin{array}{l}\text { Potassium } \\
(\%)\end{array}$ & 1.30 & 0.88 \\
\hline $\begin{array}{l}\text { Organic } \\
\text { carbon }(\%)\end{array}$ & 36.83 & 22.75 & Iron (ppm) & 248.10 & 120.50 \\
\hline $\begin{array}{l}\text { Total } \\
\text { nitrogen }(\%)\end{array}$ & 1.97 & 0.85 & Zinc (ppm) & 149.20 & 104.60 \\
\hline $\mathrm{C} / \mathrm{N}$ ratio & $24.30: 1$ & $12.71: 1$ & $\begin{array}{l}\text { Copper } \\
\text { (ppm) }\end{array}$ & 23.30 & 10.60 \\
\hline $\begin{array}{l}\text { Phosphorus } \\
(\%)\end{array}$ & 0.93 & 0.75 & $\begin{array}{l}\text { Manganese } \\
(\mathrm{ppm})\end{array}$ & 114.90 & 30.10 \\
\hline
\end{tabular}

Compost and cattle manure were added during soil preparation, as all plants received half the recommended dose of NPK fertilizers, as 100 $\mathrm{kg} / \mathrm{fed}$ calcium superphosphate was added during soil preparation and 150 $\mathrm{kg} / \mathrm{fed}$ ammonium sulfate and $50 \mathrm{~kg} / \mathrm{fed}$ potassium sulfate were added as two equal doses. The first addition was 45 days after sowing and the second one was added after 90 days from planting. All plants received normal agricultural practices whenever they needed. The harvest was after 6 months from planting in all treatments.

The following data were recorded: vegetative growth parameters i.e. plant height, number of branches per plant and fresh and dry weights of whole plant, straw, sepals and seeds per plant $(\mathrm{g})$ and per plot $(\mathrm{kg})$. Chemical ingredients determined are; i.e. active ingredients of total acidity percentage, anthocyanin percentage $(\mathrm{mg} / 100 \mathrm{~g})$ and fixed oil percentage in seeds. The chemical constituents i.e. total carbohydrates, nitrogen, and phosphorus and potassium percentage per plant were determined in roselle sepals.

Percentage of anthocyanin content $(\mathrm{mg} / 100 \mathrm{~g})$ was determined calorimetrically according to the method described by Fuleki and Francis (1968) and developed by Francis (2000) for Hibiscus sabdariffa; total acidity percentage and fixed oil percentage in seeds according to the methods of A.O.A.C. (1984); total carbohydrate, nitrogen, phosphorus and potassium percentages per plant were determined in leaves according to Dubios et al. (1956), Naguib (1969), Hucker and Catroux (1980) and Brown and Lilleland (1964), respectively.

The recorded data were statistically analyzed and means of treatments were compared using least significant difference L.S.D. test at 5\% level according to Snedecor and Cochran (1980) by using computer program of Statistics version 9 (http://www.statistix.com/freetrial.html) Analytical Software (1985). 


\section{RESULTS AND DISCUSSION}

\section{Vegetative Growth Parameters \\ 1.1. Effect of planting dates}

The main effect of planting dates declares that, all vegetative growth parameters such as plant height $(\mathrm{cm})$, number of branches per plant and fresh and dry weights of whole plant, straw, sepals and seeds per plant $(\mathrm{g})$ and per plot $(\mathrm{kg})$ have given significant differences by the variation in planting dates (Tables 3, 4 and 5). The highest vegetative growth parameters were recorded with the early planting date $\left(15^{\text {th }}\right.$ April). These results followed the same direction during both seasons. This effect might be attributed to the environmental conditions, especially temperature and day length. The increment in the weight of fruits could be attributed to the suitable growing conditions especially temperature, which was more favorable for plant development and consequently produced more number of branches, which was reflected in producing more fruits per plant and plot. The previous result is in harmony with these obtained by Tindall (1983), Morton (1987), Ghazali (1999), Schippers (2000) and Barzgaran (2011) on Hibiscus Sabdariffa and Singh et al. (2009), Blazewicz-Wozniak (2010) and Selim et al. (2013) on Foeniculum vulgare.

Table (3). Effect of planting dates, organic fertilizer and their interaction on plant height $(\mathrm{cm})$ and number of branches per plant of Hibiscus

\begin{tabular}{|c|c|c|c|c|c|c|c|c|c|c|}
\hline \multirow{4}{*}{$\begin{array}{l}\text { Planting } \\
\text { dates }(\mathrm{A})\end{array}$} & \multicolumn{10}{|c|}{ Organic fertilizer $(\mathbf{B})$} \\
\hline & Control & C.M. & Comp. & M.O.F. & $\begin{array}{c}\text { Mean } \\
\text { (B) }\end{array}$ & Control & C.M. & Comp. & M.O.F. & $\begin{array}{c}\text { Mean } \\
\text { (B) }\end{array}$ \\
\hline & \multicolumn{5}{|c|}{ Season 1 (2013) } & \multicolumn{5}{|c|}{ Season 2 (2014) } \\
\hline & \multicolumn{10}{|c|}{ Plant height $(\mathrm{cm})$} \\
\hline $15^{\text {th }}$ April & 110.00 & 148.33 & 180.67 & 205.00 & 161.00 & 112.33 & 149.67 & 183.33 & 213.33 & 164.67 \\
\hline $1^{\text {st }}$ May & 104.00 & 136.67 & 171.33 & 191.00 & 150.75 & 109.67 & 140.00 & 193.33 & 173.33 & 154.08 \\
\hline $15^{\text {th }}$ May & 105.00 & 115.00 & 155.33 & 180.00 & 138.83 & 108.67 & 116.67 & 158.00 & 183.00 & 141.58 \\
\hline Mean (A) & 106.33 & 133.33 & 169.11 & 192.00 & & 110.22 & 135.44 & 171.56 & 196.56 & \\
\hline \multirow[t]{2}{*}{$\begin{array}{l}\text { L.S.D. at } \\
5 \%\end{array}$} & \multicolumn{2}{|c|}{ A: 4.10} & $\mathrm{~B}: 6.51$ & \multicolumn{2}{|c|}{$\mathrm{AB}: 10.54$} & \multicolumn{2}{|c|}{ A: 5.13} & B: 6.18 & \multicolumn{2}{|c|}{$\mathrm{AB}: 10.54$} \\
\hline & \multicolumn{10}{|c|}{ Number of branches per plant } \\
\hline $15^{\text {th }}$ April & 5.53 & 7.00 & 9.60 & 12.33 & 8.62 & 5.77 & 7.43 & 10.37 & 13.17 & 9.18 \\
\hline $1^{\text {st }}$ May & 5.77 & 7.10 & 8.37 & 10.90 & 8.03 & 5.93 & 7.43 & 9.00 & 12.00 & 8.59 \\
\hline $15^{\text {th }}$ May & 5.03 & 6.17 & 7.67 & 9.67 & 7.13 & 5.08 & 6.22 & 7.98 & 9.97 & 7.31 \\
\hline Mean (A) & 5.44 & 6.76 & 8.54 & 10.97 & & 5.59 & 7.03 & 9.12 & 11.71 & \\
\hline $\begin{array}{l}\text { L.S.D. at } \\
5 \%\end{array}$ & A: 0.54 & & B:0.74 & $\mathrm{AB}:$ & .22 & A: 0.5 & & B: 0.77 & $\mathrm{AB}:$ & .28 \\
\hline
\end{tabular}

sabdariffa plant in 2013 and 2014 seasons.

Egyptian J. Desert Res., 65, No. 1, 153-170 (2015) 


\subsection{Effect of organic fertilizers}

Concerning the main effect of organic fertilizers, data presented in tables (3, 4 and 5) showed that, treating plants with organic fertilizers resulted in significant increases in all vegetative growth parameters compared with untreated plants (control). In this regard, mixture of organic fertilizer was the most effective for increasing the values of all growth parameters. These results hold true during both seasons. The increments in plant growth parameters using organic fertilizers treatments may be attributed primarily to that organic fertilizers application led to improve microorganism activities in soilm which led to availability of mineral element absorption (Salem and Awad, 2005), caused more vegetative growth production. Also, organic fertilizers increase the growth rate because the water and mineral uptake such as; nitrogen and phosphorus (Kaplan et al., 2009), which leads to the biomass yield improvement. This finding is in accordance with the observations of Scheffer et al. (1993) and Khalid and Shafei (2005) on Anethum graveolens, Santos et al. (2009) on Melissa officinalis and Carrubba (2009) on Coriandrum sativum.

\subsection{Effect of the interaction}

Data presented in tables (3,4 and 5) indicate that, the interaction between different planting dates and organic fertilizers had a significant effect on vegetative growth parameters. The highest values of plant height (205.00 and $213.33 \mathrm{~cm}$ ), number of branches per plant (12.33 and 13.17), fresh weight of whole plant (2462.10 and $2716.70 \mathrm{~g})$, dry weight of whole plant (714.00 and $786.67 \mathrm{~g}$ ), fresh weight of the whole plant per plot (123.10 and $135.83 \mathrm{~kg}$ ), dry weight of the whole plant per plot $(35.70$ and $39.33 \mathrm{~kg}$ ), fresh weight of straw per plant (1618.90 and1695.70 g); dry weight of straw per plant (493.63 and $508.89 \mathrm{~g}$ ), fresh weight of straw per plot (80.95 and $84.95 \mathrm{~kg})$, dry weight of straw per plot (24.68 and $25.45 \mathrm{~kg}$ ), fresh weight of sepals per plant (319.36 and $336.42 \mathrm{~g}$ ), dry weight of sepals per plant (68.67 and $70.07 \mathrm{~g}$ ), fresh weight of sepals per plot $(15.99$ and $16.82 \mathrm{~kg})$, dry weight of sepals per plot (3.13 and $3.51 \mathrm{~kg}$ ), weight of seed per plant $(90.83$ and $97.03 \mathrm{~g})$ and weight of seed per plot $(4.55$ and $4.85 \mathrm{~kg}$ ) were recorded when plants were sown on $15^{\text {th }}$ April and treated with the mixed organic fertilizer in the first and second seasons; respectively. 
Table (4). Effect of planting dates, organic fertilizer and their interaction on fresh and dry weights of whole plant; straw and sepals per plant (g) of Hibiscus sabdariffa L. plant in 2013 and 2014 seasons.

\begin{tabular}{|c|c|c|c|c|c|c|c|c|c|c|}
\hline \multirow{4}{*}{$\begin{array}{l}\text { Planting } \\
\text { dates (A) }\end{array}$} & \multicolumn{10}{|c|}{ Organic fertilizer $(B)$} \\
\hline & Control & C.M. & Comp. & M.O.F. & Mean (B) & Control & C.M. & Comp. & M.O.F. & Mean (B) \\
\hline & \multicolumn{5}{|c|}{ Season 1 (2013) } & \multicolumn{5}{|c|}{ Season 2 (2014) } \\
\hline & \multicolumn{10}{|c|}{ Fresh weight of whole plant (g) } \\
\hline $15^{\text {th }}$ April & 1156.90 & 1649.00 & 1944.90 & 2462.10 & 1803.20 & 1273.70 & 1800.00 & 2146.70 & 2716.70 & 1984.30 \\
\hline $1^{\text {st }}$ May & 1238.70 & 1515.50 & 1873.70 & 2235.70 & 1715.90 & 1345.00 & 1666.70 & 2033.30 & 2499.70 & 1886.20 \\
\hline $15^{\text {th }}$ May & 1016.40 & 1058.50 & 1508.80 & 2072.20 & 1414.00 & 1103.70 & 1150.00 & 1646.70 & 2256.70 & 1539.30 \\
\hline Mean (A) & 1137.40 & 1407.70 & 1775.80 & 2256.60 & & & 1538.90 & 1942.20 & 2491.00 & \\
\hline \multirow[t]{2}{*}{ L.S.D. at 5\% } & \multicolumn{2}{|c|}{ A: 50.44} & B: 95.19 & \multicolumn{2}{|c|}{$\mathrm{AB}: 150.97$} & A: 55.20 & \multicolumn{2}{|c|}{ B: 108.01} & \multicolumn{2}{|c|}{ AB: 170.67} \\
\hline & \multicolumn{10}{|c|}{ Dry weight of whole plant (g) } \\
\hline $15^{\text {th }}$ April & 335.51 & 478.20 & 564.03 & 714.00 & 522.94 & 366.67 & 526.67 & 620.00 & 786.67 & 575.00 \\
\hline $1^{\text {st }}$ May & 359.23 & 439.49 & 543.37 & 648.35 & 497.61 & 384.67 & 479.00 & 600.00 & 713.33 & 544.25 \\
\hline $15^{\text {th }}$ May & 294.75 & 306.96 & 437.56 & 600.92 & 410.05 & 308.00 & 332.67 & 483.00 & 663.33 & 446.75 \\
\hline Mean (A) & 329.83 & 408.22 & 514.99 & 654.42 & & 353.11 & 446.11 & 567.67 & 721.11 & \\
\hline \multirow[t]{2}{*}{ L.S.D. at $5 \%$} & \multicolumn{2}{|c|}{ A: 14.63} & B: 27.60 & \multicolumn{2}{|c|}{ AB: 43.78} & A: 14.36 & \multicolumn{2}{|r|}{ B: 31.68} & \multicolumn{2}{|c|}{ AB: 49.53} \\
\hline & \multicolumn{10}{|c|}{ Fresh weight of straw per plant (g) } \\
\hline $15^{\text {th }}$ April & 748.00 & 1077.50 & 1270.30 & 1618.90 & 1178.70 & 774.20 & 1137.30 & 1383.80 & 1695.70 & 1247.80 \\
\hline $1^{\text {st }}$ May & 791.50 & 966.60 & 1208.70 & 1444.20 & 1102.70 & 823.80 & 1043.50 & 1210.30 & 1455.40 & 1133.20 \\
\hline $15^{\text {th }}$ May & 654.40 & 679.30 & 972.40 & 1324.80 & 907.70 & 673.10 & 699.20 & 981.80 & 1370.30 & 931.10 \\
\hline Mean (A) & 731.30 & 907.80 & 1150.50 & 1462.60 & & 757.00 & 960.00 & 1192.00 & 1507.1 & \\
\hline \multirow[t]{2}{*}{ L.S.D. at $5 \%$} & \multicolumn{2}{|c|}{ A: 39.05} & B: 65.24 & \multicolumn{2}{|c|}{ AB: 104.98} & A: 66.25 & & B: 71.84 & \multicolumn{2}{|c|}{ AB: 125.66} \\
\hline & \multicolumn{10}{|c|}{ Dry weight of straw per plant (g) } \\
\hline $15^{\text {th }}$ April & 214.37 & 311.20 & 361.20 & 493.63 & 345.10 & 231.90 & 337.13 & 380.76 & 508.89 & 364.67 \\
\hline $1^{\text {st }}$ May & 227.17 & 282.30 & 342.90 & 418.23 & 317.65 & 252.12 & 308.77 & 377.47 & 457.57 & 348.98 \\
\hline $15^{\text {th }}$ May & 187.03 & 194.47 & 278.20 & 384.47 & 261.04 & 205.40 & 211.98 & 303.59 & 420.50 & 285.37 \\
\hline Mean (A) & 209.52 & 262.66 & 327.43 & 432.11 & & 229.81 & 285.96 & 353.94 & 462.32 & \\
\hline \multirow[t]{2}{*}{ L.S.D. at $5 \%$} & \multicolumn{2}{|c|}{ A: 15.00} & B: 19.11 & & 32.18 & A: 12.32 & & B: 21.88 & & 34.94 \\
\hline & & & & Fres & weight o & pals per & $\operatorname{ant}(\mathrm{g})$ & & & \\
\hline $15^{\text {th }}$ April & 185.33 & 230.33 & 254.43 & 319.63 & 247.43 & 198.26 & 234.87 & 264.40 & 336.42 & 258.49 \\
\hline $1^{\text {st }}$ May & 142.97 & 183.13 & 221.44 & 276.67 & 206.05 & 153.32 & 197.23 & 243.83 & 279.90 & 218.57 \\
\hline $15^{\text {th }}$ May & 98.42 & 150.28 & 194.72 & 252.07 & 173.87 & 103.65 & 158.73 & 203.85 & 259.13 & 181.34 \\
\hline Mean (A) & 142.24 & 187.91 & 223.53 & 282.79 & & 151.74 & 196.94 & 237.36 & 291.82 & \\
\hline L.S.D. at $5 \%$ & A: 8.0 & & B: 6.85 & & 3: 12.93 & A: 10.00 & & B: 6.11 & & $: 13.43$ \\
\hline & & & & & eight of & als per $\mathrm{p}$ & t (g) & & & \\
\hline $15^{\text {th }}$ April & 36.33 & 45.83 & 50.67 & 68.67 & 50.38 & 41.50 & 49.27 & 55.27 & 70.07 & 54.03 \\
\hline $\mathbf{1}^{\text {st }}$ May & 28.23 & 34.97 & 44.03 & 57.67 & 41.23 & 30.70 & 41.00 & 48.90 & 61.23 & 45.46 \\
\hline $15^{\text {th }}$ May & 20.13 & 31.83 & 38.07 & 51.70 & 35.43 & 20.47 & 32.57 & 39.23 & 54.80 & 36.77 \\
\hline $\operatorname{Mean}(\mathbf{A})$ & 28.23 & 37.54 & 44.26 & 59.34 & & 30.89 & 40.94 & 47.80 & 62.03 & \\
\hline L.S.D. at 5\% & A: 2.2 & & B: 1.82 & & $B: 3.50$ & A: 1.79 & & $: 1.62$ & & $: 2.99$ \\
\hline
\end{tabular}


Table (5). Effect of planting dates, organic fertilizer and their interaction on fresh and dry weights of whole plant; straw and sepals per plot (kg.) of Hibiscus sabdariffa L. plant in 2013 and 2014 seasons.

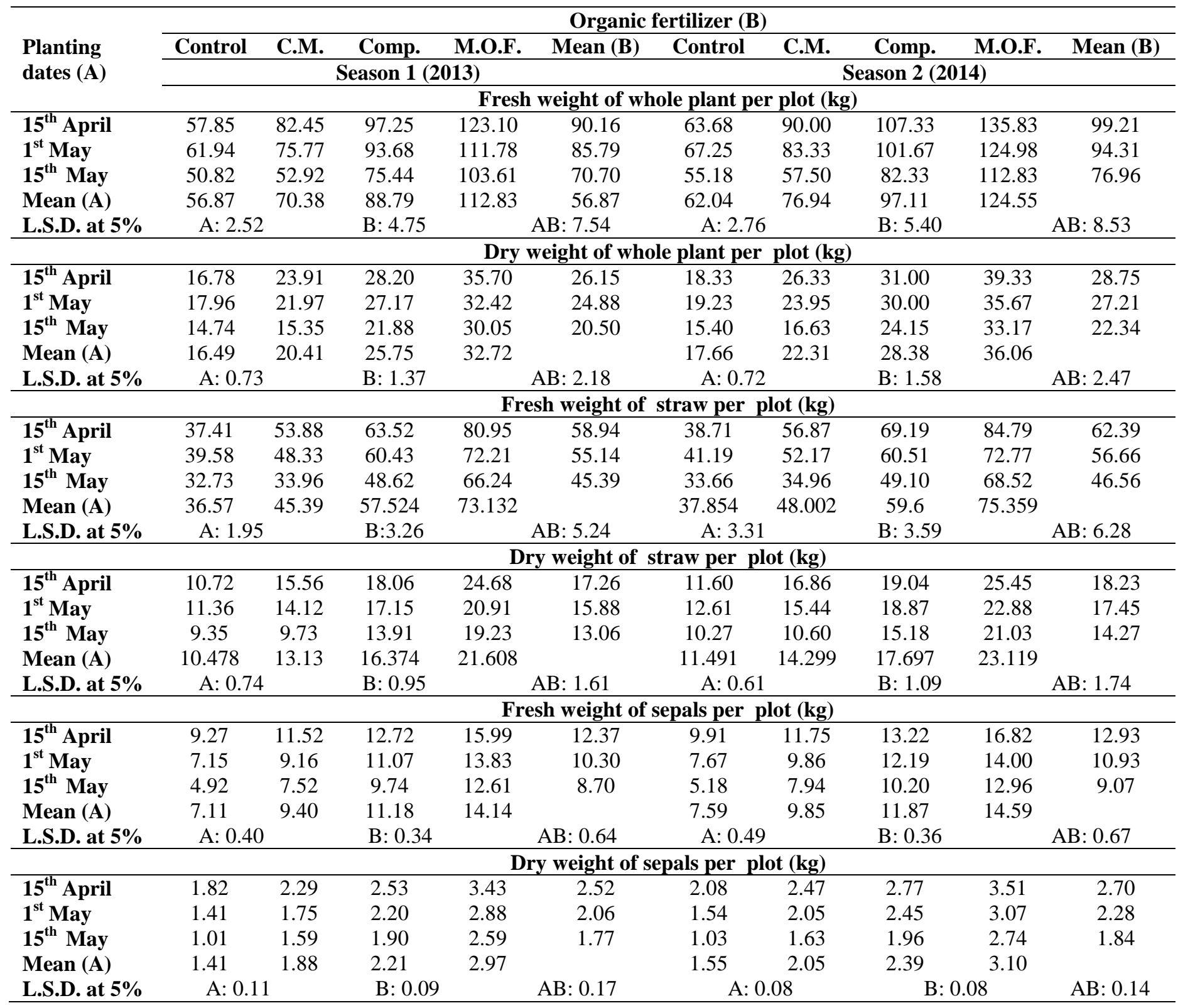


Cultivating plants on $15^{\text {th }}$ April and treatment with mixed organic fertilizer increased vegetative growth parameters, followed by $15^{\text {th }}$ April with compost and then $15^{\text {th }}$ April with cattle manure, and this increase was significant. The planting date on $15^{\text {th }}$ April with cattle manure and then $15^{\text {th }}$ April without fertilizer and $1^{\text {st }}$ May with mixed organic fertilizer increased the vegetative growth parameters, but this increase was insignificant in the first and second seasons; respectively. This effect might be due to that mixture (compost and cattle manure) had some macro and micronutrients, which enhanced plant growth (Amine-Khodja et al., 2006). Also organic fertilizers may contain many species of living organisms, which release phytohormones; such as $\mathrm{GA}_{3}$, IAA and CYT, which stimulate plant growth, nutrient absorption and photosynthesis and this is reflected on plant dry matter accumulation.

\section{Chemical Ingredients}

\subsection{Effect of planting dates}

Data presented in table (6), reveal that, the chemical ingredients; such as total acidity percentage, anthocyanin percentage $(\mathrm{mg} / 100 \mathrm{~g})$ and fixed oil seed content were significantly different with the different planting dates. The highest values of these parameters were pertinent to the early planting date $\left(15^{\text {th }}\right.$ April). Similar trend was recorded by Nnebue et al. (2014), Ado et al. (2015), Futuless et al. (2010) and Seghatoleslami et al. (2013) on roselle plants.

The increment in the anthocyanin could be attributed to not only high sepals yield per plant, but also the response of relatively high percentage in the sepals as a result of early planting date. This results are in line with those reported by Sudeep et al. (2005); Ayub et al. (2008) on Foeniculum vulgare; Sree and Reddy (2004); Gahannavard et al. (2009) on Ricinus communis and Seghatoleslami and Mousavi (2009) on Calendula officinalis. 
Table (6). Effect of planting dates, organic fertilizer and their interaction on seed weight per plant $(\mathrm{g})$ and per plot, anthocyanin content $(\mathrm{mg} / 100 \mathrm{~g})$ and total acidity percentage of Hibiscus sabdariffa plant in 2013 and 2014 seasons.

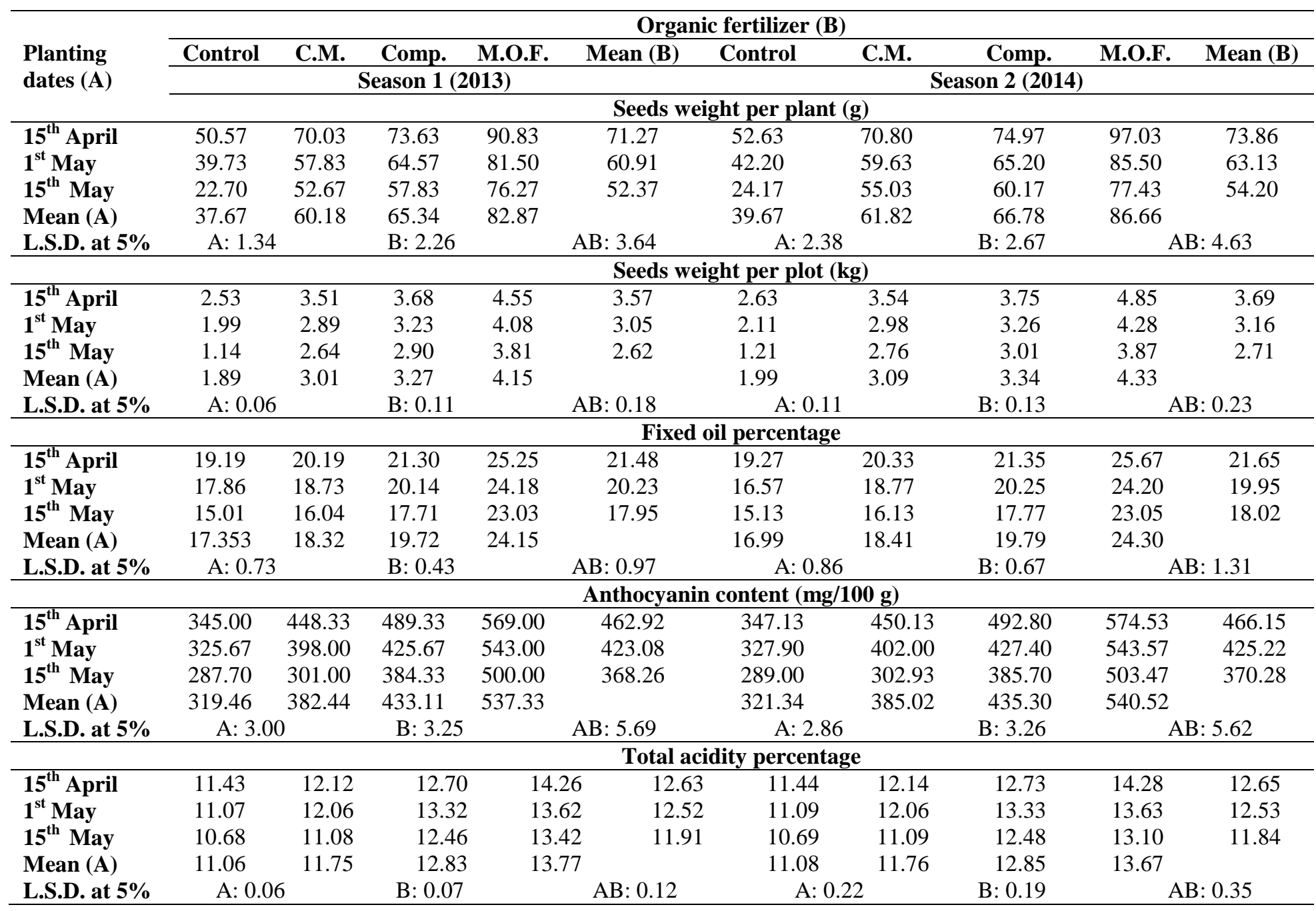




\subsection{Effect of organic fertilizers}

Regarding the chemical ingredients determination such as total acidity percentage, anthocyanin percentage $(\mathrm{mg} / 100 \mathrm{~g})$ and fixed oil seed content as affected by organic fertilizers treatments from data reported in table (6), it was found that, treated plants with organic fertilizers resulted in significant increase in these characters compared with untreated plants (control). The treatment of mixed organic fertilizer recorded the significant increase in both seasons, respectively. These results are in line with those reported by Biasi et al. (2009) on Ocimum basilicum and Amer (2008) on Dracocephalum moldavica.

\subsection{Effect of the interaction}

Among the different interaction treatments between the different planting dates and organic fertilizers, the treatment of sowing in $15^{\text {th }}$ April and treatment with mixed organic fertilizer gave the highest total anthocyanin (569.00 and $574.53 \mathrm{mg} / 100 \mathrm{~g}$ ), total acidity (14.25 and 14.28\%) and fixed oil seed content (25.25 and $25.67 \%)$ during in the first and second seasons, respectively, as shown in table (6).

Planting date on $15^{\text {th }}$ April with mixed organic fertilizer, followed by $15^{\text {th }}$ April with compost and $15^{\text {th }}$ April without fertilization showed an increase in the total acidity and fixed oil seed content and the increase was significant. However the plant cultivation in $15^{\text {th }}$ April with mixed organic fertilizer increased total anthocyanin, followed by $15^{\text {th }}$ April with compost, then $15^{\text {th }}$ April with cattle manure, and this increase was significant in both seasons (2013 and 2014). The treatment of $15^{\text {th }}$ April without fertilization followed by $1^{\text {st }}$ May with mixed organic fertilizer increased the total acidity and fixed oil seed content, but this increase was insignificant.

\section{Chemical Constituents}

\subsection{Effect of planting dates}

Data presented in table (7) show that, nitrogen, phosphorus, potassium and total carbohydrates percentages were significantly different at planting date of $15^{\text {th }}$ April, which gave the highest values of these characters compared with other planting dates. The increment in the NPK and total carbohydrates content as a result of early planting was probably due to the fact that the earliest planted plants had comparatively more time for their vegetative growth and consequently, the absorbency of these elements was increased so, the percentages of these elements can be increased.

This result is in harmony with those obtained by Nagabhushanam and Raghavaiah (2005), Rezvani et al. (2008) on Ricinus communis, Futuless et al. (2010), Ado et al. (2015) on Hibiscus sabdariffa, Sanjeet et al. (2010), El-Khayat and Gouda (2005) and Abd El-Wahab and Mehasen (2009) on Foeniculum vulgare. 
Table (7). Effect of planting dates, organic fertilizer and their interaction on nitrogen, phosphorus, potassium and total carbohydrate percentage of Hibiscus sabdariffa plant in 2013 and 2014 seasons.

\begin{tabular}{|c|c|c|c|c|c|c|c|c|c|c|}
\hline \multirow{4}{*}{$\begin{array}{l}\text { Planting date } \\
\text { (A) }\end{array}$} & \multicolumn{10}{|c|}{ Organic fertilizer (B) } \\
\hline & Control & C.M. & Comp. & M.O.F. & $\begin{array}{c}\text { Mean } \\
\text { (B) }\end{array}$ & Control & C.M. & Comp. & M.O.F. & $\begin{array}{c}\text { Mean } \\
\text { (B) }\end{array}$ \\
\hline & \multicolumn{5}{|c|}{ Season 1 (2013) } & \multicolumn{5}{|c|}{ Season 2 (2014) } \\
\hline & \multicolumn{10}{|c|}{ Nitrogen percentage } \\
\hline $15^{\text {th }}$ April & 3.43 & 3.67 & 4.04 & 4.84 & 4.00 & 3.45 & 3.69 & 4.06 & 4.90 & 4.03 \\
\hline $1^{\text {st }}$ May & 3.17 & 2.96 & 3.74 & 4.38 & 3.56 & 3.18 & 2.97 & 3.75 & 4.40 & 3.58 \\
\hline $15^{\text {th }}$ May & 1.96 & 2.43 & 3.07 & 4.08 & 2.89 & 1.98 & 2.45 & 3.10 & 4.10 & 2.91 \\
\hline Mean (A) & 2.86 & 3.02 & 3.62 & 4.44 & & 2.87 & 3.04 & 3.64 & 4.47 & \\
\hline \multirow[t]{2}{*}{ L.S.D. at $5 \%$} & A: 0.04 & & B: 0.04 & & 0.08 & A: $0 .($ & & B: 0.03 & & 0.08 \\
\hline & \multicolumn{10}{|c|}{ Phosphorus percentage } \\
\hline $15^{\text {th }}$ April & 0.066 & 0.496 & 0.879 & 1.180 & 0.655 & 0.073 & 0.513 & 0.903 & 1.254 & 0.686 \\
\hline $1^{\text {st }}$ May & 0.037 & 0.361 & 0.769 & 0.996 & 0.541 & 0.042 & 0.396 & 0.786 & 1.020 & 0.561 \\
\hline $15^{\text {th }}$ May & 0.048 & 0.117 & 0.580 & 0.868 & 0.403 & 0.065 & 0.124 & 0.610 & 0.899 & 0.424 \\
\hline Mean (A) & 0.050 & 0.325 & 0.743 & 1.015 & & 0.060 & 0.344 & 0.766 & 1.057 & \\
\hline \multirow[t]{2}{*}{ L.S.D. at $5 \%$} & A: 0.069 & & B: 0.067 & $\mathrm{AB}$ & 0.121 & A: 0.0 & & B: 0.071 & & 0.123 \\
\hline & \multicolumn{10}{|c|}{ Potassium percentage } \\
\hline $15^{\text {th }}$ April & 1.94 & 2.45 & 3.36 & 4.32 & 3.02 & 2.02 & 2.60 & 3.63 & 4.61 & 3.21 \\
\hline $1^{\text {st }}$ May & 2.02 & 2.49 & 2.93 & 3.82 & 2.81 & 2.08 & 2.60 & 3.15 & 4.20 & 3.01 \\
\hline $15^{\text {th }}$ May & 1.76 & 2.16 & 2.68 & 3.38 & 2.50 & 1.78 & 2.18 & 2.79 & 3.49 & 2.56 \\
\hline Mean (A) & 1.91 & 2.36 & 2.99 & 3.84 & & 1.96 & 2.46 & 3.19 & 4.10 & \\
\hline \multirow[t]{2}{*}{ L.S.D. at $5 \%$} & \multicolumn{5}{|c|}{ AB: 0.42} & \multicolumn{2}{|c|}{ A: 0.19} & B: 0.27 & \multicolumn{2}{|c|}{ AB: 0.44} \\
\hline & \multicolumn{10}{|c|}{ Total carbohydrates percentage } \\
\hline $15^{\text {th }}$ April & 17.85 & 18.43 & 19.25 & 22.23 & 19.44 & 17.87 & 18.43 & 19.25 & 22.64 & 19.55 \\
\hline $1^{\text {st }}$ May & 17.15 & 17.62 & 18.98 & 20.83 & 18.65 & 17.17 & 17.64 & 19.02 & 20.86 & 18.67 \\
\hline $15^{\text {th }}$ May & 16.12 & 17.12 & 18.21 & 19.43 & 17.72 & 16.13 & 17.10 & 18.22 & 19.44 & 17.72 \\
\hline $\operatorname{Mean}(\mathbf{A})$ & 17.04 & 17.73 & 18.81 & 20.83 & & 17.06 & 17.72 & 18.83 & 20.98 & \\
\hline L.S.D. at 5\% & A: 0.05 & & B: 0.06 & $\mathrm{AB}$ & 0.010 & A: 0. & & B: 0.14 & & 0.24 \\
\hline
\end{tabular}

\subsection{Effect of organic fertilizers}

Results presented in table (7) declare that, total carbohydrates, nitrogen, phosphorus and potassium percentages were significantly increased when plants were treated with organic fertilizers compared to untreated plants. The highest values of all these characters were obtained when mixed organic fertilizer was applied during both seasons. Similar results were reported by Khalil and El-Sherbeny (2003) on Mentha species, El-Sherbeny et al. (2007) on Ruta graveolens and Shaalan (2005) on Borage officinalis.

Organic fertilizer is the source of $\mathrm{N}$ and other nutrients for plants (such as phosphorus, potassium, calcium,, iron, zinc and copper) that can make valuable contributions to soil organic matter, can improve physical 
fertility, and is a center for biological activities as reported by Khalid and Shafei (2005) on Anethum graveolens.

\subsection{Effect of the interaction}

The combined effect between different planting dates and organic fertilizers (Table, 7) show that, the highest values of total carbohydrate percentage (22.23 and 22.64\%), nitrogen percentages (4.84 and $4.90 \%)$, phosphorus percentages $(0.400$ and $0.402 \%)$ and potassium percentages (4.69 and 5.16\%) were recorded when plants were sown on $15^{\text {th }}$ April and supplied with mixed organic fertilizer during both seasons; respectively.

The beneficial effect of different organic fertilizers on the chemical constituents may be due to the role of macro and micro nutrients provided by these fertilizers, which stimulate the metabolic processes and photosynthetic apparatus that leads to more photosynthesis and carbohydrate synthesis. The beneficial effect of organic fertilizer on chemical composition were observed by Hussein et al. (2006) on Dracocephalum moldavica and El-Sherbeny et al. (2005) on Sideritis montana.

\section{REFERENCES}

A.O.A.C. (1984). In "Official's Methods of Analysis". Association of Official Analytical Chemists. Washington D.C., USA.

Abd El-Wahab, M.A. and H.R.A. Mehasen (2009). Effect of locations and sowing date on Foeniculum vulgare, Mill. Indian fennel type under Upper Egypt conditions. J. Applied Sci. Res., 5 (6): 677-685.

Ado, G., I.I. Indabawa and K.D. Sani (2015). Effect of planting date and seed density on the growth and yield of roselle Hibiscus sabdariffa (Linn). International Conference on Chemical, Environmental and Biological Sciences (CEBS-2015) March 18-19, Dubai (UAE).

Amer, H.M. (2008). Effect of planting date and organic manure on the growth, production and active ingredients of dragonhead plant (Dracocephalum moldavica L.). M.Sc. Thesis, Fac. Agric. Cairo Univ., Egypt.

Amine-Khodja, A., O. Trubetskaya, O. Trubetskoj, L. Cavani, C. Ciavatta, and G. Guyot (2006). Humic-like substances extracted from composts can promote the photo degradation of lrgarol 1051 in solar light. Chemosphere, 62: 1021-7.

Analytical Software (1985). Data Analysis Software for Researchers 1985.

Ayub, M., M.A. Nadeem, A. Tanveer, M. Tahir, M.T.Y. Saqib and R. Nawaz (2008). Effect of different sowing methods and times on the growth and yield of fennel (Foeniculum vulgare, Mill). Pak. J. Bot., 40 (1): 259-264.

Aziz, E., N. Gad and N.M. Badran (2007). Effect of cobalt and nickel on plant growth, yield and of flavonoids content of Hibiscus sabdariffa L. Aust. J. Basic Appl. Sci., 1 (2): 73-78.

Egyptian J. Desert Res., 65, No. 1, 153-170 (2015) 
Babatinde, F.E., T.O. Oseni, B.M. Auwalu, G.N. and Udom (2002). Effect of sowing dates, untra-row spacings and nitrogen fertilizers of the productivity of red variant roselle (Hibiscus sabdariffa L). Pertanika J. Trap. Agric. Sci., 25 (2): 99-106.

Badran, F.S. and M.S. Safwat (2004). Response of fennel plants to organic manure and bio-fertilizers in replacement of chemical fertilization. Egyptian J. Agric. Res., 82 (2): 247-256.

Barzgaran, T. (2011). Effects of irrigation and planting date on agronomic traits and yield of roselle. M.Sc. Thesis, Dept. of Agriculture, Islamic Azad Univ. Birjand Branch, Iran. 111 pp.

Biasi, L.A., E.M. Machado, A.P. Kowalski, D. Signor, M.A. Alves, F.I. Lima, C. Deschamps, L.C. Cocco and A.P. Scheer (2009). Organic fertilization in the production, yield and chemical composition of basil chemo type eugenol. Horticultura Brasileira, 27 (1): 35-39.

Blazewicz-Wozniak, M. (2010). Effect of soil and plant covering and sowing time on the yield of fennel bulbs grown from sowing directly in the field. Folia Hort., 22 (2): 59-66.

Brown, J.D. and O. Lilleland (1964). Rapid determination of potassium and sodium in plant material and soil extracts by flame photometry. Proc. Amer. Soc. Hort. Sci., 48: 341-46.

Carrubba, A. (2009). Nitrogen fertilization in coriander (Coriandrum sativum L.): a review and meta-analysis. Journal of the Science of Food and Agriculture, 89 (6): 921-926.

Dubios, H., K.A. Gillo, J. Hamillon, R. Robers and I. Smith (1956). Colorimetric method for determination of sugars and related substances. Anal. Chem., 28: 350.

El-Khayat, A.S.M. and H.A.H. Gouda (2005). Effect of sowing date and potassium fertilization on growth, yield and chemical composition of Foeniculum vulgare, Mill. plants. Annals of Agric. Sci., Moshtohor. Egypt, Fac. of Agric., Zagazig Univ., 43 (3): 1245-1269.

El-Sherbeny, S.E., M.Y. Khalil and N.Y. Naguib (2005). Influence of compost levels and suitable spacing on the productivity of Sideritis montana plants recently cultivated under Egyptian conditions. Bull. Fac. Agric. Cairo Univ., 56: 373-392.

El-Sherbeny, S.E., M.S. Hussein and M.Y. Khalil (2007). Improving the productivity of Ruta graveolens L. plants cultivated under different compost levels and various planting distance. American Eurasian. J. Agric. and Environ. Sci., 2 (9): 271 -281.

Francis, F.J. (2000). Anthocyanins and betalains composition: composition and applications. Cereal Foods World, 45: 208-213.

Fuleki, T. and F.J. Francis (1968). Quantitative methods for anthocyanin. 1. Extraction and determination of total anthocyanin in cranberries. J. Food Sci., 33: 72-77. 
Futuless, K.N., M. Kwaga and A.A. Clement (2010). Effect of sowing date on calyx yield and yield components of roselle Hibiscus sabdariffa L. In northern guinea savanna. New York Science Journal, 3 (11): 211-230.

Gahannavard, S.H., M. Tagbakhsh and A. Bernosi (2009). Effect of different planting dates and plant densities on oil and protein yields of castor bean crop. National Congress of Oilseed Plants of Esfahan University, Iran, p. 359-361.

Ghazali, M. (1999). Characterization and utilization of roselle. Food Science and Biotechnology on-line. University Putra, Malaysia.

Herrera, E., N. Trembla, B. Desroches and A. Gosselin (1997). Optimization of substrate and nutrient solution for organic cultivation of medicinal transplants in multi-cell flats. J. Herbs, Species Med. Plants, 4: 6982.

Hucker, T.W.G. and G. Catroux (1980). Phosphorus in sewage ridge and animal waste slurries. Proceeding of the EEC Seminar, Haren (Gr); Groningen Netherlands, 12, 13 June.

Hussein, M.N., S.E. El-Sherbeny, M.Y. Khalil, N.Y. Naguib and S.M. Aly (2006). Growth characters and chemical constituents of Dracocephalum moldavica L. plants in relation to compost fertilizer and planting distance. Scientia Horticulture, 108: 322-331.

Kaplan, M., I. Kocabas, I. Sonmez and H. Kalkan (2009). The effects of different organic manure applications on the dry weight and the essential oil quantity of sage (Salvia fruticosa Mill.). Acta. Horticulture, 826: 147-152.

Khalid, K.A. and A.M. Shafei (2005). Productivity of dill (Anethum graveolens L.) as influenced by different organic manure rates and sources. Arab Universities J. Agric. Sci., 13 (3): 901-913.

Khalil, M.Y. (2002). Influence of compost and foliar fertilization on growth and chemical composition of Rosmarinus officinalis and Tagetes erecta. Egypt. J. Appl. Sci., 17: 684-699.

Khalil, M.Y. and S.E. El-Sherbeny (2003). Improving the productivity of three Mentha species recently cultivated under Egyptian condition. Egypt. J. App. Sci., 18 (1): 285-300.

Khandar, U.R. and K.B. Nigam (1986). Effect of farmyard manure and fertility on growth and yield of ginger (Zingiber officinalis). Ind. J. Agric. Sci., 66: 549-550.

Mathur, G., G. Owen, H. Dinel and M. Schnitzer (1993). Determination of compost biomaturity. Biol. Agric. Hort., 10: 65-85.

Mohamed, R., J. Fernandez, M. Pineda and M. Aguilar (2007). Roselle (Hibiscus sabdariffa) seed oil is rich source of Ǵ- tocopherol. J. Food Sci., 72: S207-S211.

Morton, J. (1987). In "Roselle". Fruits of Warm Climates. Julia F. Morton (ed.), CRC Press, Miami, Florida, p. 281-286. 
Nagabhushanam, U. and C.V. Raghavaiah (2005).Seeding date and irrigation effects on the productivity and oil quality of post monsoon grown castor, Ricinus communis L. in Alf sols. J. Oilseeds Res., 22 (1): 206-208.

Naguib, M.I. (1969). Colorimetric determination of nitrogen components of plant tissues. Bull. Fac. Sci., Cairo Univ., 43: 1-9.

Nnebue, O.M., I.J. Ogoke, O.P. Obilo, C.M. Agu, G.O. Ihejirika and F.O. Ojiako (2014). Estimation of planting dates for roselle [Hibiscus Safdariffa (Linn)] in the humid tropical environment of Owerri, southeastren Nigreria. Agrosearc., 14 (2): 168-178.

Okosun L.A. (2000). Effect of plant density, sowing data and fertilizer on the growth and yield of roselle (Hibiscus sabdariffa L.) in the Sudan Savannah. Ph.D. Thesis presented to the Postgraduate School Usmanu Danfodiyo University, Sokoto, Nigeria, 186 pp.

Oyewole C.I. and M. Mera (2010). Response of roselle (Hibiscus sabdariffa L.) to rate of inorganic and farmyard fertilizers in the Sudan Savannah ecological zone of Nigeria. African J. Agric Res. 5 (17): 235-239.

Peng-Kong, W., S. Yusof; H.M. Ghazali and Y.B. Man (2002). Physicochemical characteristics of roselle (Hibiscus sabdariffa L.). J. Nutr. Food Sci. 32: 68-73.

Rezvani Mogaddam, P., Z. Rezazade, A.A. Mohammad Abadi and A. Sharif (2008). Effect of planting date and different treatments fertilizer on yield, yield components and percent of grain oil of castor bean plant. Iranian J. Field Crops Res., 6 (2): 303-313.

Salem, A.G. and A.M. Awad (2005). Response of coriander plants to organic and mineral fertilizers in sandy soils. Egyptian Journal of Agricultural Research, 83 (2): 829-858.

Sanjeet, B., P.P. Singh, I.S. Naruka, S.S. Rathore and R.P.S. Shaktawat (2010). Effect of date of sowing and nitrogen levels on growth, yield and quality of fennel. Indian J. Hort., 67 (4): 518-524.

Santos, M.F., M.C. Mendonca, J.L.S. Carvalho Filho, I.B. Dantas, R. SilvaMann and A.F. Blank (2009). Cattle manure and biofertilizer on the cultivation of lemon balm (Melissa officinalis L.). Revista Brasileira de Plant as Medicines, 11 (4): 355-359.

Sanyo, A.C. (1981). Food coloring agents from Hibiscus flower Pulp Co., Ltd., dap. Kakai, Tokyo, Japan, 81: 141-358. (Chem Abst. 96: 19882).

Scheffer, M.C., P. Ronzelli Junior and H.S. Koehler (1993). Influence of organic fertilization on the biomass, yield and composition of the essential oil of Achillea millefolium L. Acta Horticulturae, 331: 109114.

Schippers, A.A. (2000). In “African Indigenous Vegetation". Natural Resources Institute. Publisher Chatham, UK, 95 pp.

Egyptian J. Desert Res., 65, No. 1, 153-170 (2015) 
Seghatoleslami, M.J. and G.R. Mousavi (2009). The effects of sowing date and plant density on seed and flower yield of pot marigold (Calendula officinalis). Acta Hort., 2: 371-376.

Seghatoleslami, M.J., S.G. Mousavi and T. Barzgaran (2013). Effect of irrigation and planting date on morpho-physiological traits and yield of roselle (Hibiscus sabdariffa). The Journal of Animal and Plant Sciences, 23 (1): 256-260.

Selim, S.M., M. Ebtsam, M. Abdella, M.S.H. Tawfik and A.I. Abou-Sreea (2013). Effect of sowing date, sow spacing and bio-fertilizer on yield and oil quality of fennel plant (Foeniculum vulgare, Mill.). Australian Journal of Basic and Applied Sciences, 7 (2): 882-894.

Shaalan, M. N. (2005). Effect of compost and different sources of biofertilizers on borage plants (Borage officinalis L.). Egypt. J. Agric. Research, 83 (1): $271-284$.

Singh, S.K. S.M. Tripathi and A.K. Dwivedi (2009). Effect of planting dates, sowing methods and row spacing on yield of fennel. Annals of Hort., 2 (2): 249-250.

Snedecor, G.W. and W.G. Cochran (1980). In "Statistical Methods" ( $7^{\text {th }}$ Ed.) Iowa State Univ., Press, Amer, Iowa, USA.

Sree, P.S.S and B.B. Reddy (2004). Effect of sowing date on performance of castor (Ricinus communis) cultivars during summer in rice (Oryza sativa) fallows. Indian Journal of Agronomy, 49 (3): 189-191.

Sudeep, S., G.S. Buttar and S.P. Singh (2005). Fennel response to sowing dates and row spacing. Haryana J. of Agronomy, 21 (2): 202 -208.

Tara, A., O. Brien and V.B. Allen (1996). Growth of peppermint in compost. J. Herbs, Spices Med. Plants, 4: 19-27.

Timothy, E. and K.N. Futuless (2014). Influence of sowing date and different levels of nitrogen fertilizer on the performance of roselle (Hibiscus Sabdariffa L.) in Mubi Adamawa State, Nigeria. Journal of Agriculture and Allied Sciences, 3: 200-215.

Tindal, H.D. (1983). In "Vegetables in Tropics McMillan Education Haundmills", Bassingtock Hamshire, 734 pp.

Twain, J.B., W.E. Gerald, A.H. Mark and J.R. Larry (2001). Flowering in crimson clover as affected by planting date. Crop Science, 42: 242247. 


\section{تأثير مواعيد الزراعة المختلفة والمعاملة بالأسمدة العضوية على نمو وإنتاجية نباتات الكركديه}

إلهام محم عطية ورانية مرتضى خاطر" قسم النباتات الطبية و العطرية ، مركز بحوث الصحر اءو، المطرية، القاهرة، مصر

أجريت هذه الدراسة في محطة بحوث القنطرة شرق التابعة لمركز بحوث الصحر اء خلاء خلال

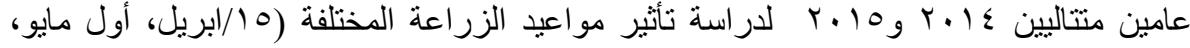

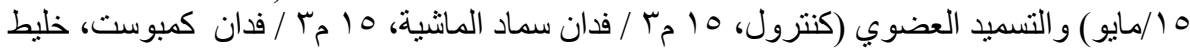

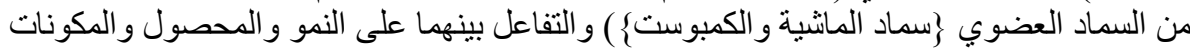

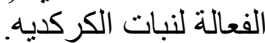

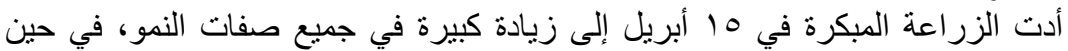

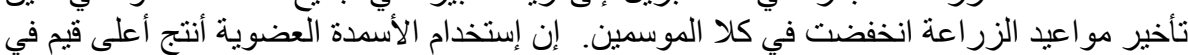

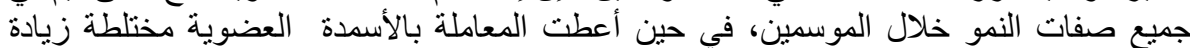

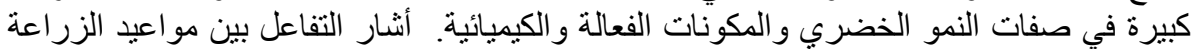

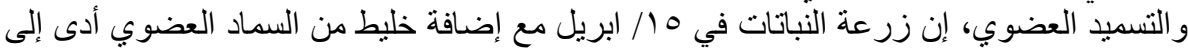

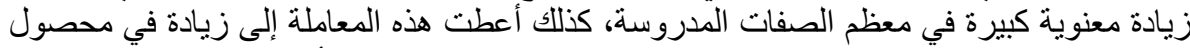

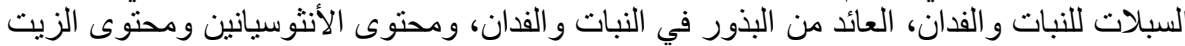
الثابت في البذور مقارنة بالمعاملات الأخرى.

Egyptian J. Desert Res., 65, No. 1, 153-170 (2015) 